\title{
Cytoplasmic ERß1 expression is associated with survival of patients with Stage IV lung adenocarcinoma and an EGFR mutation at exon 21 L858R subsequent to treatment with EGFR-TKIs
}

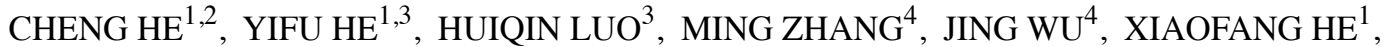 \\ YUYING FU ${ }^{1}$, WENJU CHEN ${ }^{1}$ and JINKUN ZOU ${ }^{1}$ \\ ${ }^{1}$ Department of Medical Oncology, Anhui Provincial Hospital Affiliated to Anhui Medical University; \\ Departments of ${ }^{2}$ Thoracic Oncology, ${ }^{3}$ Medical Oncology and \\ ${ }^{4}$ Pathology, Anhui Provincial Cancer Hospital, Hefei, Anhui 230000, P.R. China
}

Received October 1, 2018; Accepted February 27, 2019

DOI: $10.3892 / 01.2019 .10348$

\begin{abstract}
The present study assessed whether estrogen receptor (ER) $\beta 1$ is associated with the survival of patients with advanced lung adenocarcinoma, with or without mutations of the epidermal growth factor receptor (EGFR) following treatment with EGFR-tyrosine kinase inhibitors (TKIs). Pathologically confirmed stage IV lung adenocarcinomas were assessed for EGFR mutations and ER $\beta 1$ expression. Progression-free survival (PFS) and overall survival (OS) were estimated using the Kaplan-Meier method and the log-rank test. A total of 122 out of the 201 (60.7\%) patients had EGFR mutations, 64 (31.8\%) of which were EGFR Del19 and 58 mutations (28.9\%) were EGFR exon 21 L858R mutation. The presence of EGFR mutations was significantly increased in female patients compared with male patients $(\mathrm{P}<0.001)$ and in non-smokers compared with smokers $(\mathrm{P}<0.001)$. Patients with EGFR mutations had a significantly improved PFS and OS compared with patients without EGFR mutations treated with EGFR-TKIs. Furthermore, ER $\beta 1$ expression was significantly increased in patients with EGFR mutations compared with patients without EGFR mutations $(\mathrm{P}=0.001)$. However, the median PFS $(\mathrm{P}=0.005)$ and OS $(\mathrm{P}=0.002)$ of patients carrying the EGFR exon $21 \mathrm{~L} 858 \mathrm{R}$ mutation was significantly decreased in patients with tumors where ER $\beta 1$ cytoplasmic expression was high. The multivariate analysis demonstrated that ER $\beta 1$ expression was the only independent predictor of PFS $(\mathrm{P}=0.002)$ and $\mathrm{OS}(\mathrm{P}=0.003)$ in
\end{abstract}

Correspondence to: Professor Yifu He, Department of Medical Oncology, Anhui Provincial Hospital Affiliated to Anhui Medical University, 17 Lujiang Road, Hefei, Anhui 230000, P.R. China E-mail: yifuhe@fsyy.ustc.edu.cn

Key words: estrogen receptor $\beta 1$, epidermal growth factor receptor mutation, lung adenocarcinoma, tyrosine kinase inhibitor, prognostic marker patients carrying the EGFR exon 21 L858R mutation. The data demonstrated that ER $\beta 1$ expression may predict outcomes of patients with lung adenocarcinoma treated with EGFR-TKI.

\section{Introduction}

Lung cancer is the leading cause of cancer-associated mortality worldwide and non-small cell lung cancer (NSCLC) accounts for $80-85 \%$ of all lung cancer cases (1). Mutations and gene amplifications of epidermal growth factor receptor (EGFR) frequently occur in NSCLC, and EGFR-tyrosine kinase inhibitors (EGFR-TKIs) are regularly used to treat patients with NSCLC and prolong progression-free survival (PFS) $(2,3)$. Thus, it is recommended to screen for EGFR mutations in patients with NSCLC and that patients with sensitizing EGFR mutations are treated with first-line EGFR-TKIs, whereas patients with NSCLC wihtout EGFR mutation or unknown mutational status are treated with platinum-based chemotherapy $(4,5)$. In the clinic, the majority of patients with EGFR mutations initially respond very well to EGFR-TKIs; however, a large proportion of them eventually develop drug resistance (6). The underlying molecular mechanisms of drug resistance may be due to receptor tyrosine-protein kinase erbB-2 (HER2) amplification and EGFR T790M mutation, MET proto-oncogene, receptor tyrosine kinase (c-MET) amplification, phosphatidylinositol-4,5-bisphosphate 3-kinase catalytic subunit $\alpha$ (PIK3CA) mutation or B-Raf proto-oncogene, serine/threonine kinase (BRAF) mutations in tumor tissues (7). However, the specific molecular mechanisms require further investigation. For example, previous studies demonstrated that estrogen receptor (ER) $\beta$ was overexpressed in NSCLC tissue specimens, which may be associated with resistance to treatment with EGFR-TKIs in patients with NSCLC $(8,9)$. ER $\beta$ is the most commonly observed subtype of ER expressed in lung cancer $(8,9)$. Previous studies have suggested cross-talk between the ER $\beta$ and EGFR signaling pathways in lung cancer (10-12). ER $\beta$ is frequently overexpressed in NSCLC with EGFR mutations, particularly in lung 
adenocarcinoma $(13,14)$, and ER $\beta$ expression was reported to be associated with the prognosis of NSCLC with EGFR mutations subsequent to treatment with EGFR-TKIs (15-17). There are five known isoforms of ER $\beta$, and ER $\beta 1$ is the only known full-length and functional ER $\beta$ isoform expressed in various cells and tissues (18), and is the most relevant prognostic factor of all ER $\beta$ isoforms for patients with NSCLC (9).

To date, the presence of a number of EGFR mutations have been demonstrated to occur in NSCLC (19), each of which may contribute to different outcomes of patients treated with EGFR-TKIs; however, two EGFR mutations, exon 19 deletion (Del19) and the substitution L858R in exon 21, account for $80-90 \%$ of all EGFR mutations in NSCLC (20), and patients with NSCLC carrying these mutations respond favourably to treatment with EGFR-TKI $(2,3)$. In contrast, other EGFR mutations, including G719X, L861Q and a de novo exon 20 T790M mutation, account for $\sim 10 \%$ of the known EGFR mutations in NSCLC, and only certain patients responded favourably to treatment with EGFR-TKI (21). In addition, patients with the T790M mutation demonstrated resistance to treatment with first generation EGFR-TKIs (22). Previous studies have demonstrated that treatment of patients with NSCLC carrying Del19 mutation with EGFR-TKIs improved outcomes compared with the patients carrying the L858R mutation $(23,24)$. In the present study, ER $\beta 1$ expression was retrospectively assessed in 201 lung adenocarcinoma tissue specimens, and the ER $\beta 1$ expression and survival of patients with lung adenocarcinoma carrying the EGFR Del19 or L858R mutation subsequent to treatment with EGFR-TKIs were examined. The present study was designed to confirm data from previous studies $(23,24)$, and additionally provide useful information regarding treatment of patients with NSCLC with EGFR-TKIs or a combination of other drugs.

\section{Patients and methods}

Patients and treatment. Patients who were pathologically diagnosed with stage IV TNM lung adenocarcinoma were evaluated for eligibility (25). The inclusion criteria were: i) Patients with data pertaining to EGFR mutations; and ii) treatment with EGFR-TKIs or chemotherapy. The exclusion criteria were: i) Patients that had left hospital; ii) patients that had refused any chemotherapy or an EGFR test, or iii) there was no sufficient tissue specimen for the EGFR and immunohistochemistry (IHC) tests. Thus, 201 patients were eligible for the present study. Tissue samples from patients, for EGFR mutation analysis, were retrospectively collected from The Department of Thoracic Oncology, Anhui Provincial Cancer Hospital (Hefei, China) between January 2012 and June 2014. The cohort of patients had stage IV disease; thus, there were no patients that underwent tumor resection. The median age was 65 years (range, $27-84$ years) and $72.1 \%$ were females. Lung cancer tissues were obtained through transbronchial biopsy or fine needle aspiration for histological diagnosis of NSCLC. The present study was approved by The Ethics Committee of Anhui Provincial Cancer Hospital, which waived patient consent due to mortality of all the individuals.

In terms of treatment options, patients with lung adenocarcinoma with no evidence of EGFR mutations were administered pemetrexed in combination with two 4-week cycles of cisplatin/carboplatin (area under the curve=5). From the cohort, two patients with a relatively uncommon EGFR 19Del plus T790M mutation, which may not have responded well to treatment with EGFR-TKI $(20,21)$, also received chemotherapy as it was in doubt whether such patients would respond to the first generation of EGFR-TKIs. Patients with common EGFR mutations and two patients with uncommon EGFR mutations (one each of S768I/L858R and 19Del/G719X mutation) were administered the first-line therapy of gefitinib ( $250 \mathrm{mg} /$ day), erlotinib (150 mg/day) or icotinib (125 mg, three times a day) for between 4 and 17.6 months (discontinued after occurrence of drug resistance). Treatment with EGFR-TKIs were discontinued when CT scans identified enhanced disease progression or if treatment toxicity was deemed unacceptable. For these patients, chemotherapy or the best supportive care were the options considered thereafter.

Patient assessment and follow-up. The clinicopathological data of the patients, including age, sex, smoking history, TNM stage and brain metastasis, were retrieved from their medical records and are presented in Table I. Clinically, all patients were evaluated on a monthly basis and their follow-up consisted of a physical examination, including the Eastern Cooperative Oncology Group performance status (26), laboratory tests and electrocardiography, whereas tumor burdens were assessed monthly or bimonthly using CT. Non-smokers were defined as individuals who had smoked $<100$ cigarettes in their lifetime, whereas others were defined as smokers. The effectiveness of chemotherapy or targeted therapy was evaluated with the Response Evaluation Criteria in Solid Tumors (RECIST) 1.1 (27) and disease progression was defined as $\geq 20 \%$ increase in the diameter of a tumor lesion following treatment with EGFR-TKI or chemotherapy according to RECIST 1.1 (27). The PFS was calculated as the interval from initial treatment to the progression of the disease, mortality of any cause or the last follow-up. The overall survival (OS) was calculated as the interval from initial treatment to mortality from any cause or the last follow-up. The survival data were obtained through the review of medical records, telephone follow-up or contact with the local Household Registration Department.

DNA extraction and detection of EGFR mutations. Genomic DNA was extracted from formalin-fixed, paraffin-embedded tumor tissue specimens using the Cobas ${ }^{\circledR}$ DNA Sample Preparation Kit according to the manufacturer's protocol (Roche Molecular Diagnostics, Pleasanton, CA, USA). The presence of EGFR mutations was assessed using a Cobas z 480 real-time PCR system (Roche Molecular Diagnostics) which is capable of detecting 42 EGFR mutations (28).

IHC. All IHC steps were performed on a BenchMark XT system (Ventana Medical Systems, Inc., Tucson, AZ, USA), according to the manufacturer's protocol. Briefly, paraffin-embedded tissue sections of a $4-\mu \mathrm{m}$ thickness were fixed in $10 \%$ neutral-buffered formalin for $24 \mathrm{~h}$ at room temperature and deparaffinized and subsequently placed into a $60^{\circ} \mathrm{C}$ oven for $2 \mathrm{~h}$. To block endogenous peroxidase activity, $3 \%$ hydrogen peroxide was used for $8 \mathrm{~min}$ at $37^{\circ} \mathrm{C}$. A mouse monoclonal anti-human ER $\beta 1$ antibody PPG5/10 (1:50; cat. 
Table I. Clinicopathological characteristics of 201 patients with stage IV lung carcinoma.

\begin{tabular}{|c|c|c|c|c|}
\hline \multirow[b]{2}{*}{ Clinicopathological characteristic } & \multirow[b]{2}{*}{$\mathrm{n}$} & \multicolumn{2}{|c|}{$\begin{array}{l}\text { Epidermal growth factor } \\
\text { receptor mutations, n }(\%)\end{array}$} & \multirow[b]{2}{*}{ P-value } \\
\hline & & Mutation & No mutation & \\
\hline Age (years) & & & & 0.314 \\
\hline$\geq 65$ & 103 & $66(64.1)$ & $37(36.9)$ & \\
\hline$<65$ & 98 & $56(57.1)$ & $42(42.9)$ & \\
\hline Sex & & & & $<0.001^{\mathrm{a}}$ \\
\hline Male & 56 & $22(39.3)$ & $34(60.7)$ & \\
\hline Female & 145 & $100(69.0)$ & $45(31.0)$ & \\
\hline Smoking status & & & & $<0.001^{\mathrm{a}}$ \\
\hline Smoker & 62 & $20(32.3)$ & $42(67.7)$ & \\
\hline Never-smoker & 139 & $102(73.4)$ & $37(26.6)$ & \\
\hline ECOG performance status & & & & 0.675 \\
\hline 0 & 108 & $67(62.0)$ & $41(38.0)$ & \\
\hline$\geq 1$ & 93 & $55(59.1)$ & $38(40.9)$ & \\
\hline Brain metastasis & & & & 0.605 \\
\hline Yes & 115 & $64(55.6)$ & $51(44.4)$ & \\
\hline No & 86 & $51(59.3)$ & $35(40.7)$ & \\
\hline
\end{tabular}

${ }^{\mathrm{a}} \mathrm{P}<0.001$. ECOG, Eastern Cooperative Oncology Group.

no. M7292; Dako; Agilent Technologies, Inc., Santa Clara, CA, USA) was incubated with the tissue sections for $32 \mathrm{~min}$ at $37^{\circ} \mathrm{C}$. Subsequently, the slides were incubated with a ultraView universal HRP Multimer, which contains a cocktail of HRP labeled antibodies (goat anti-mouse IgG, goat anti-mouse IgM and goat anti-rabbit) (prediluted; cat. no. 760-500; Ventana Medical Systems, Inc.) for $8 \mathrm{~min}$ at $37^{\circ} \mathrm{C}$. Finally, the tissue sections were counterstained with hematoxylin for $16 \mathrm{~min}$ at $37^{\circ} \mathrm{C}$ and assessed under a light microscope (Olympus Corporation, Tokyo, Japan) at $\mathrm{x} 10$ magnification using the Allred scoring system according to previous studies $(14,28)$. ER $\beta$ expression was divided into nuclear or cytoplasmic staining and scored based on the proportion of positive cells ( 0 , no staining at all; $1, \leq 1 \% ; 2,2-10 \% ; 3,11-33 \% ; 4,34-66 \%$; and $5,>67 \%)$ and the staining intensity $(0$, no staining; 1, weak; 2 , moderate; and 3 , strong staining). The evaluation of the IHC staining was performed independently by two pathologists who were blinded to the identity of the patients. The staining index of the cytoplasmic or nuclear score was subsequently reached by the addition of the staining proportion and intensity to provide a score between 0 and 8 (Fig. 1). Any disagreements were resolved by reviewing the immunostained sections to reach a consensus. High or low ER $\beta$ expression was defined according to a previous study (29). The median of the cytoplasmic scores of ER $\beta 1$ immunostaining was 4; thus, the low level of the cytoplasmically immunostaining was defined as $\leq 4$, whereas $>4$ was classified as a high level of cytoplasmic ER $\beta 1$ expression.

Statistical analysis. All statistical analyses were performed using SPSS 20.0 (IBM Corporation, Armonk, NY, USA). The primary endpoint of the treatment responses was the PFS, whereas the secondary endpoint was the OS. The median PFS and OS were estimated using the Kaplan-Meier curves and statistically analyzed using the log-rank test. Where appropriate, the data were additionally presented as the $95 \%$ confidence intervals (CI) and the hazard ratios (HRs) with associated $95 \% \mathrm{CI}$. The variables significantly associated with survival in a univariate analysis using the log-rank test were further assessed using a multivariate analysis with the Cox proportional model. $\mathrm{P}<0.05$ was considered to indicate a statistically significant difference.

\section{Results}

Characteristics of patients. In the present study, a total of 761 patients diagnosed with lung adenocarcinoma between January 2012 and June 2014 (Fig. 2) were retrospectively reviewed. Due to the nature of the study, 201 patients with TNM stage IV with a known EGFR mutation status were included in the analysis. The demographic and baseline characteristics are listed in Table I. The EGFR mutation frequency was significantly higher in female patients $(69.0 \%)$ compared with male patients $(39.3 \% ; \mathrm{P}<0.001)$ and also higher in non-smokers $(73.4 \%)$ compared with smokers $(32.3 \%$; $\mathrm{P}<0.001)$. Other clinicopathological data did not demonstrate statistical significance between patients with or without EGFR mutations (Table I).

In the present cohort, the median PFS was 10 months (95\% CI; 9.5-10.5 months) and the median OS was 21 months (95\% CI; 20.1-21.9 months). Patients with EGFR mutations demonstrated a significantly increased median PFS (12 vs. 6 months, $\mathrm{P}<0.001$; Fig. 3A), and a longer median OS (23 vs. 16 months, $\mathrm{P}<0.001$; Fig. 3B) compared with patients without EGFR mutations subsequent to treatment 

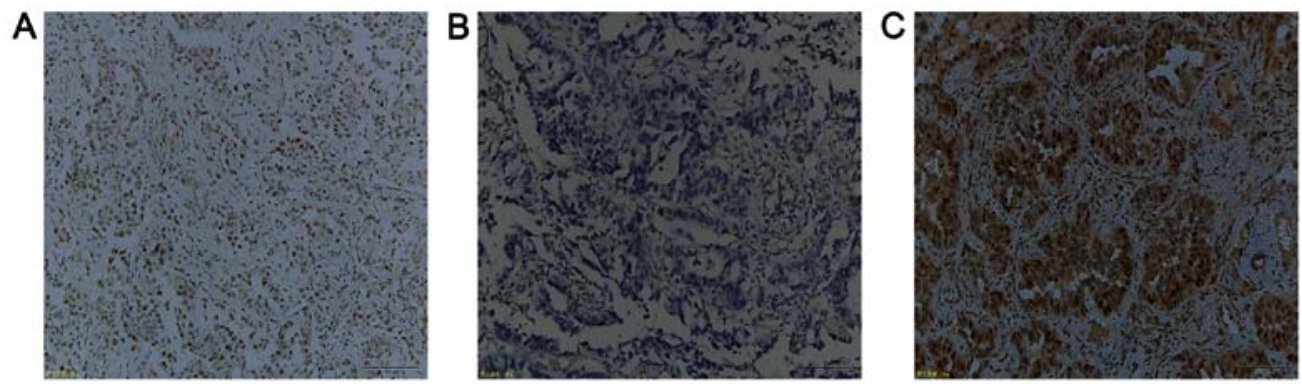

Figure 1. Immunohistochemical assessment of ER $\beta 1$ expression in lung adenocarcinoma tissue specimens. (A) The Allred scoring system of ER $\beta 1$ expression in tissue specimens. Cytoplasmic score of $8+$ nuclear score of $8=$ total score of 16 (tissue specimen from a patient with EGFR Del19 mutation). (B) The cytoplasmic score of $3+$ nuclear score of $7=$ total score of 10 (tissue specimen from a patient with EGFR exon 21 L858R mutation). (C) The cytoplasmic score $0+$ nuclear score $0=$ total score 0 (tissue specimen from a patient without any EGFR mutation). Scale bar, $100 \mu \mathrm{m}$. ER $\beta 1$, estrogen receptor $\beta 1$; EGFR, epidermal growth factor.

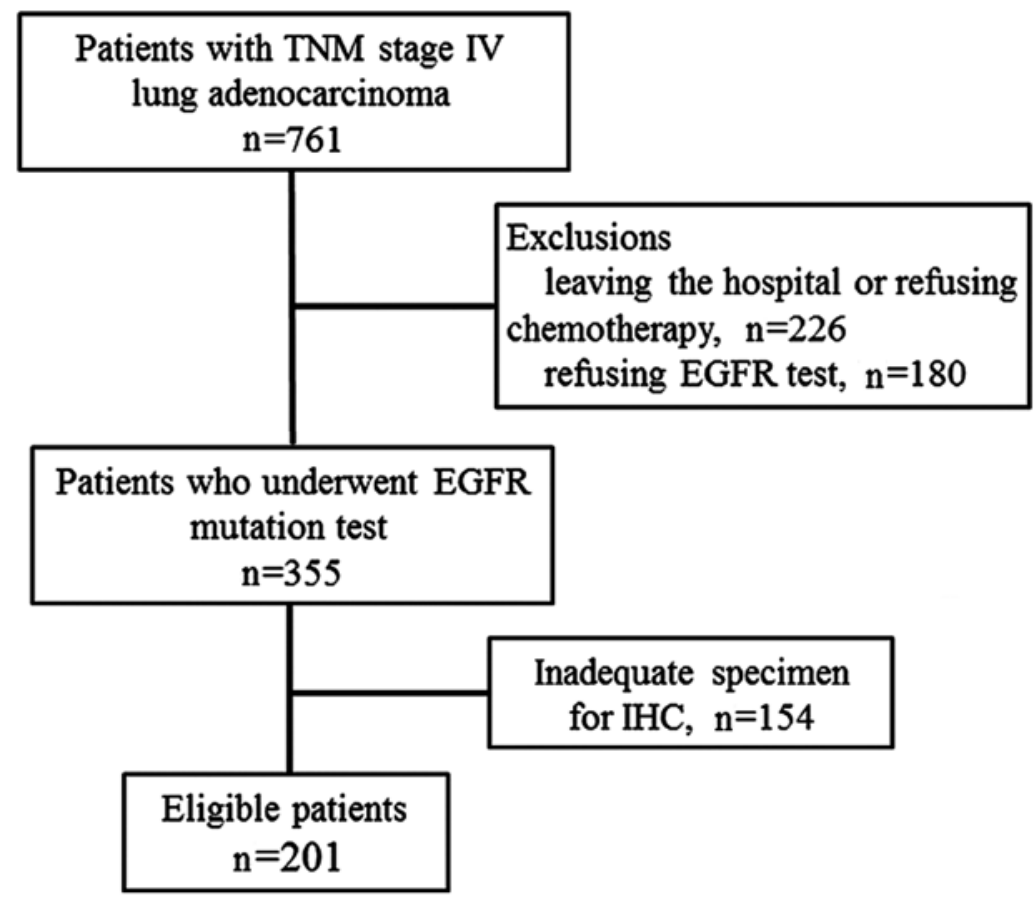

Figure 2. Flow diagram of inclusion and exclusion criteria for cohort selection. TNM, tumor node metastasis; EGFR, epidermal growth factor receptor; IHC, immunohistochemistry.

with EGFR-TKIs. The median PFS was additionally significantly increased among patients with EGFR Del19 compared with the EGFR exon 21 L858R mutation (14 vs. 9 months, $\mathrm{P}<0.001$; Fig. 3C). A similar trend was observed for the median OS (25 vs. 20 months, $\mathrm{P}<0.001$; Fig. 3D).

ERß1 expression is associated with survival of patients with EGFR mutations. The median nuclear ER $\beta 1$ score was 6 , which was set as the cut-off value to distinguish between low and high expression of nuclear ER $\beta 1$. In addition, the median total score of cytoplasmic and nuclear ER $\beta 1$ immunostaining was 9 , which was used to distinguish between the low and high levels of total cytoplasmic and nuclear ER $\beta 1$ immunostaining in tumor tissues (Fig. 4). ER $\beta 1$ was expressed in the cytoplasm and nuclei of 98 patients with lung adenocarcinoma, expressed in the cytoplasm in 74 patients and expressed in the nucleus in 99 patients (Table II). ER $\beta 1$ expression was significantly increased in patients with EGFR mutations (71 patients, 58.2\%) compared with patients without EGFR mutations (27 patients, $34.1 \% ; \mathrm{P}=0.001)$. However, no significant difference in $\mathrm{ER} \beta 1$ expression was observed between females and males, irrespective of the localization of ER $\beta 1$. Furthermore, there were no significant associations between other clinical features and overall ER $\beta 1$ expression. No significant differences were observed between overall ER $\beta 1$ expression and the PFS $(\mathrm{P}=0.161$; Fig. $5 \mathrm{~A})$ or $\mathrm{OS}(\mathrm{P}=0.458$; Fig. $5 \mathrm{~B})$ of all the patients. Similarly, there was no association between ER $\beta 1$ expression and PFS ( $\mathrm{P}=0.534$; Fig. $5 \mathrm{C})$ or $\mathrm{OS}(\mathrm{P}=0.425$; Fig. $5 \mathrm{D})$ in patients with EGFR mutations.

Furthermore, there was no association between high/low nuclear ER $\beta 1$ and the PFS ( $\mathrm{P}=0.674$; Fig. $6 \mathrm{~A})$ or $\mathrm{OS}(\mathrm{P}=0.207$; Fig. 6B). Similarly, there was no association between nuclear ER $\beta 1$ expression and PFS ( $\mathrm{P}=0.519$; Fig. 6C) or OS $(\mathrm{P}=0.352$; Fig. 6D) in patients with EGFR mutations. There was no significant difference in the PFS (14 vs. 10 months; $\mathrm{P}=0.694$; Fig. 7A) or OS (25 vs. 23 months; $\mathrm{P}=0.936$; Fig. 7B) in 
Table II. Association of ER $\beta 1$ expression with clinicopathological parameters of 201 lung adenocarcinoma patients.

\begin{tabular}{|c|c|c|c|c|c|c|c|c|c|}
\hline \multirow[b]{2}{*}{ Characteristic } & \multicolumn{3}{|c|}{$\begin{array}{c}\text { Cytoplasmic } \\
\text { expression of ER } \beta 1\end{array}$} & \multicolumn{3}{|c|}{$\begin{array}{c}\text { Nuclear } \\
\text { expression of ER } \beta 1\end{array}$} & \multicolumn{3}{|c|}{$\begin{array}{c}\text { Total } \\
\text { expression of ER } \beta 1\end{array}$} \\
\hline & High (n) & Low (n) & P-value & High (n) & Low (n) & P-value & High (n) & Low (n) & P-value \\
\hline Age (years) & & & 0.57 & & & 0.29 & & & 0.36 \\
\hline$\geq 65$ & 36 & 67 & & 47 & 56 & & 47 & 56 & \\
\hline$<65$ & 38 & 60 & & 52 & 46 & & 51 & 47 & \\
\hline Sex & & & 0.59 & & & 0.41 & & & 0.17 \\
\hline Male & 19 & 37 & & 25 & 31 & & 23 & 33 & \\
\hline Female & 55 & 90 & & 74 & 71 & & 75 & 70 & \\
\hline Smoking status & & & 0.12 & & & 0.87 & & & 0.19 \\
\hline Ever smoker & 18 & 44 & & 30 & 32 & & 26 & 36 & \\
\hline Never smoker & 56 & 83 & & 69 & 70 & & 72 & 67 & \\
\hline Performance status & & & 0.27 & & & 0.95 & & & 0.34 \\
\hline 0 & 36 & 72 & & 53 & 55 & & 56 & 52 & \\
\hline$\geq 1$ & 38 & 55 & & 46 & 47 & & 42 & 51 & \\
\hline Brain metastasis & & & 0.92 & & & 0.45 & & & 0.98 \\
\hline Yes & 42 & 73 & & 54 & 61 & & 56 & 59 & \\
\hline No & 32 & 54 & & 45 & 41 & & 42 & 44 & \\
\hline EGFR-mutant status & & & 0.12 & & & 0.40 & & & $0.001^{\mathrm{a}}$ \\
\hline Yes & 50 & 72 & & 63 & 59 & & 71 & 51 & \\
\hline No & 24 & 55 & & 36 & 43 & & 27 & 52 & \\
\hline
\end{tabular}

${ }^{\mathrm{a}}<<0.01$. ER $\beta 1$, estrogen receptor $\beta 1$.

A

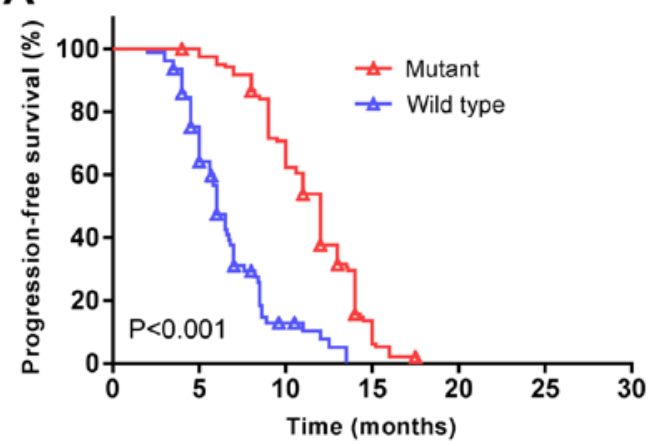

\section{C}

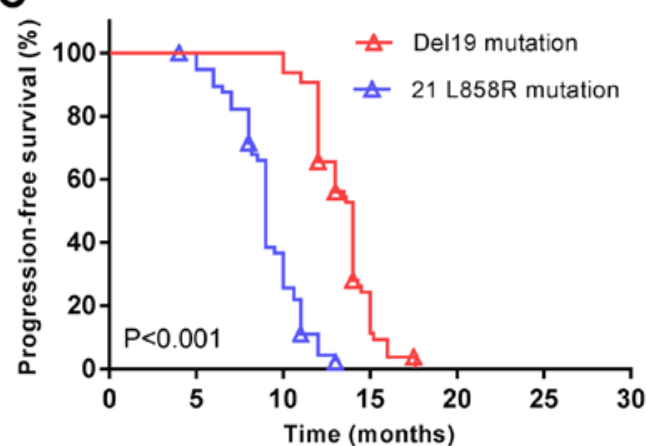

B

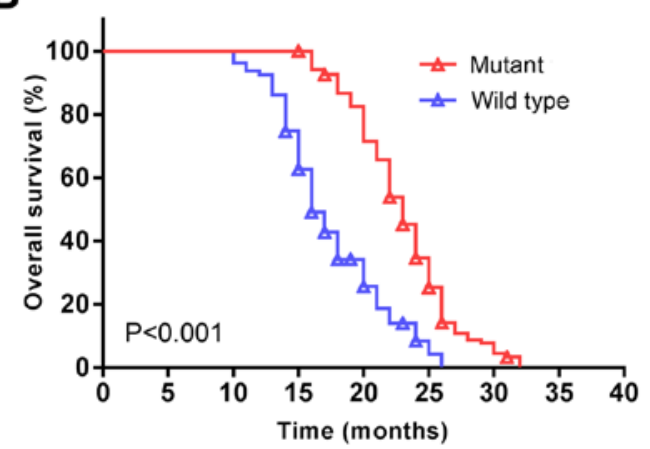

D

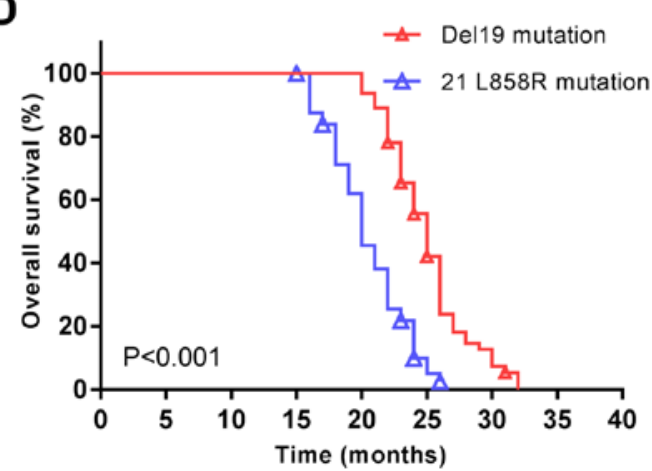

Figure 3. An exon 21 L858R EGFR mutation is associated with a decreased survival rate of patients with non-small cell lung cancer. (A) PFS and (B) OS were significantly decreased in patients with an EGFR mutation. $\mathrm{P}<0.001$. (C) PFS and (D) OS were significantly decreased in patients carrying the 21 L858R EGFR mutation compared with patients carrying the exon Del19 mutation. $\mathrm{P}<0.001$. Symbols represent censored observations. EGFR, epidermal growth factor receptor; PFS, progression free survival; OS, overall survival. 

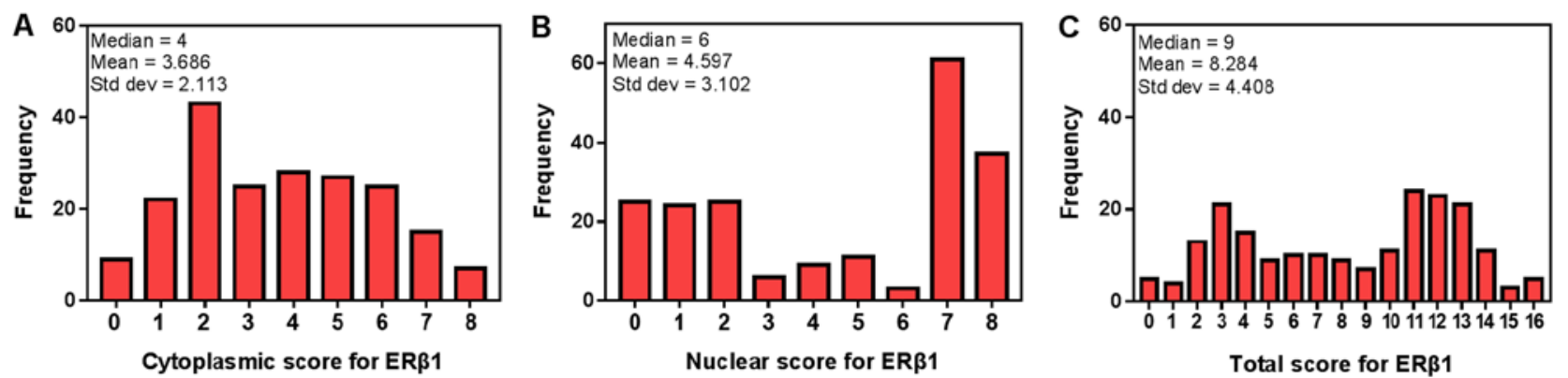

Figure 4. Immunostaining scores of ER $\beta 1$ expression. A histogram of the (A) cytoplasmic scores, (B) nuclear scores (C) and total scores of ER $\beta 1$ expression in 201 cases of patients with lung adenocarcinoma. ER $\beta 1$, estrogen receptor- $\beta 1$.
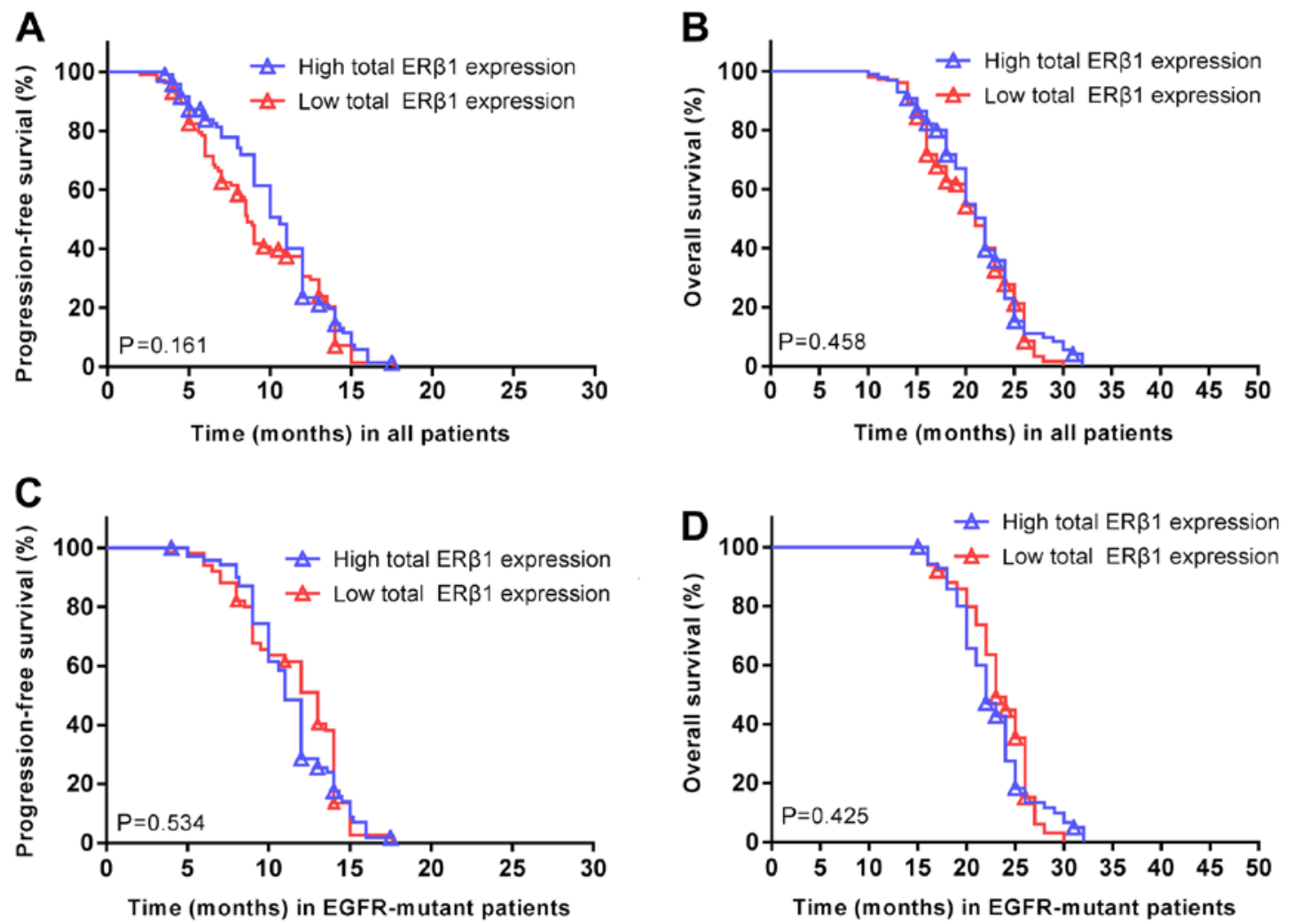

Figure 5. Total cellular ER $\beta 1$ expression is not associated with the survival of patients with NSCLC. (A) PFS and (B) OS were not significantly altered in patients with high $\mathrm{ER} \beta 1$ expression compared with low expression. $\mathrm{P}=0.161 ; \mathrm{P}=0.458$, respectively. (C) PFS and (D) OS in patients with EGFR-mutant NSCLC were not significantly altered in patients with high $E R \beta 1$ expression compared with low expression. $\mathrm{P}=0.534 ; \mathrm{P}=0.425$, respectively. Symbols represent censored observations. NSCLC, non-small cell lung cancer; PFS, progression free survival; OS, overall survival; ER $\beta 1$, estrogen receptor $\beta 1$; EGFR, epidermal growth factor receptor.

patients with high/low cytoplasmic ER $\beta 1$ expression in the male patients carrying EGFR mutations. Similarly, no significant differences were in PFS (10 vs. 12 months; P=0.216; Fig. 7C) or OS (21 vs. 23 months; $P=0.208$; Fig. 7D) were observed in the female EGFR-mutant patients with high/low expression. There were no associations between EGFR mutations and nuclear ER $\beta 1$ expression or between patients carrying EGFR mutations and total ER $\beta 1$ levels in males and females (Table II).

The median PFS of patients carrying EGFR exon 21 L858R mutations was significantly shorter in high cytoplasmic ER $\beta 1$ tumors (8.0 months; 95\% CI, 6.2-9.8 months) compared with low cytoplasmic ER $\beta 1$-expressing tumors (9.5 months; 95\% CI, 8.9-10.1 months; $\mathrm{P}=0.005 ; \mathrm{HR}=1.977$; 95\% CI, 1.126-3.469; Fig. 8A). Similarly, the median OS was significantly shorter in high cytoplasmic ER $\beta 1$-expressing tumors (18.0 months; 95\% CI, 16.3-19.7 months) compared with low cytoplasmic ER $\beta 1$-expressing tumors (22.0 months; 95\% CI, 20.8-23.2 months; $\mathrm{P}=0.002$; HR=2.217; 95\% CI, 1.246-3.945; Fig. 8B). A significant difference between the numbers of patients with high cytoplasmic ER $\beta 1$ expression compared with low cytoplasmic expression in patients with EGFR mutations may have skewed the data. A total of $122(60.7 \%)$ had EGFR mutations, of which, 64 (31.8\%) were EGFR Del19 mutations and 58 (28.9\%) were EGFR exon 21 L858R mutation. In patients with EGFR mutations, two patients had the Del19 and an additional T790M mutation, one patient had a S768I/L858R mutation and one patient had a 19Del/G719X mutation (Table III). There were no 
A

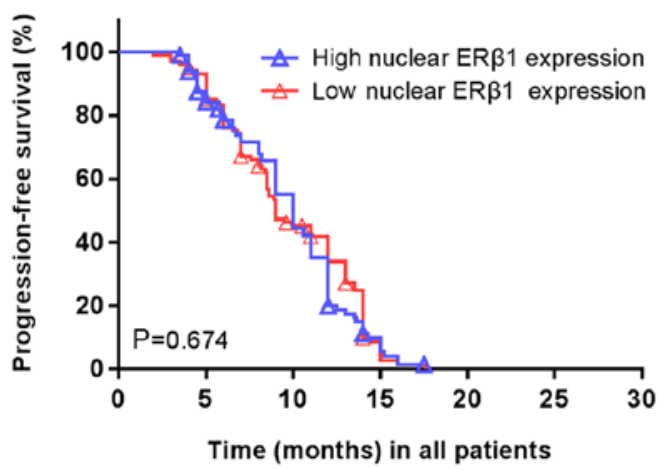

C

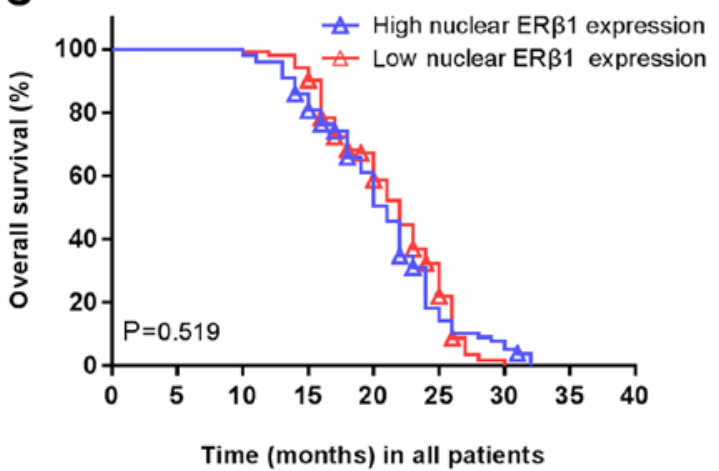

B

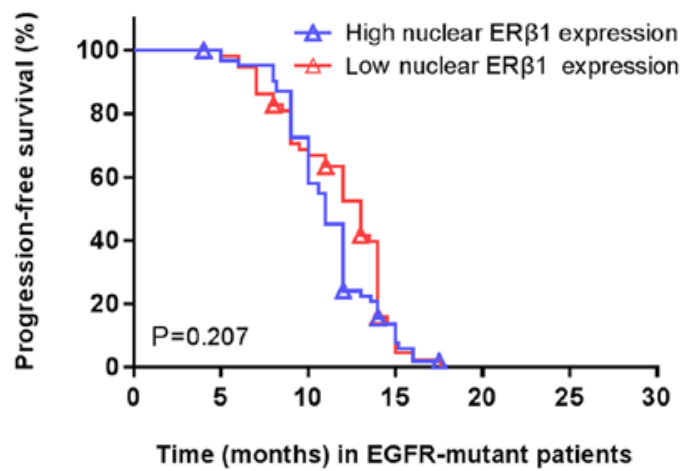

D

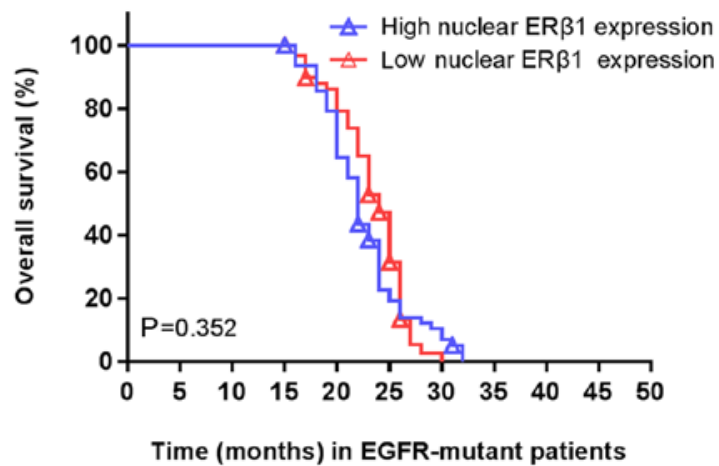

Figure 6. Nuclear ER $\beta 1$ expression is not associated with the survival of patients with. (A) PFS and (B) OS were not significantly altered in patients with high ER $\beta 1$ expression compared with low expression. $\mathrm{P}=0.674 ; \mathrm{P}=0.207$, respectively. (C) PFS and (D) OS in patients with EGFR-mutant non-small cell lung cancer were not significantly altered in patients with high ER $\beta 1$ expression compared with low expression. $\mathrm{P}=0.519 ; \mathrm{P}=0.342$, respectively. Symbols represent censored observations. NSCLC, non-small cell lung cancer; PFS, progression free survival; OS, overall survival; ER $\beta 1$ estrogen receptor $\beta 1$; EGFR, epidermal growth factor receptor.

significant differences in ER $\beta 1$ expression between patients with a EGFR Del19 or exon 21 L858R mutation, irrespective of the localization of the protein, although it was observed that the frequency of high cytoplasmic ER $\beta 1$ expression was lower (23 patients, 39.6\%) compared with that of low expression (35 patients, 60.1\%) in patients with EGFR L858R mutation, which was similar to patients carrying EGFR Del19 mutations, this difference was not significant (Table III). In patients with the Del19 EGFR mutation, the survival rate did not differ significantly between patients with high or low nuclear ER $\beta 1$ expression (Fig. 9A and B, respectively) or cytoplasmic expression (Fig. 9C and D).

Multivariate analysis. The multivariate analysis of ER $\beta 1$ expression, age, sex, tobacco smoking and tumor brain metastasis demonstrated that only ER $\beta 1$ expression was an independent predictor of PFS (HR=2.847; 95\% CI, 1.456 to 5.565; $\mathrm{P}=0.002$ ) and $\mathrm{OS}(\mathrm{HR}=2.639 ; 95 \% \mathrm{CI}, 1.283$ to $5.036 ; \mathrm{P}=0.003)$ in patients carrying EGFR 21 L858R mutation (Tables IV and V).

\section{Discussion}

Lung cancer is a major cause of cancer-associated mortality worldwide (30). Tobacco smoking is the single largest contributing risk factor in lung cancer development, although certain patients with lung cancer are non-smokers, suggesting that other factors are also important in the pathogenesis of lung cancer. These risk factors may induce mutations of EGFR or alter expression of other genes (6-16). For example, aberrant $\mathrm{ER} \beta$ expression is associated with lung cancer development and progression $(9,11,31)$, and the survival of patients with NSCLC (32-36). Therefore, the present study further assessed ER $\beta 1$ expression in lung adenocarcinoma tissue specimens and determined the outcomes of patients with or without EGFR mutations following treatment with EGFR-TKI. The present study demonstrated that $60.7 \%$ of patients carried an EGFR mutation and the majority of these mutations were the EGFR Del19 and exon 21 L858R mutations. The presence of EGFR mutations was significantly higher in females than male patients, and in non-smokers compared with smokers. The median PFS of the cohort of patients was 10 months, whereas the median OS was 21 months. Patients with EGFR mutations had a significantly improved median PFS compared with patients without EGFR mutations following treatment with EGFR-TKIs, and the median PFS was also longer in patients with EGFR Del19 compared with the EGFR exon 21 L858R mutation. Additionally, the median OS was significantly improved in patients with EGFR mutations compared with patients without EGFR mutations. In addition, ER $\beta 1$ expression was increased in patients with EGFR mutations compared with patients without EGFR mutations. The median PFS and OS were significantly shorter in patients with the EGFR exon 21 L858R mutation, and in patients with cytoplasmic ER $\beta 1$-expressed tumor. Multivariate analysis demonstrated 
A
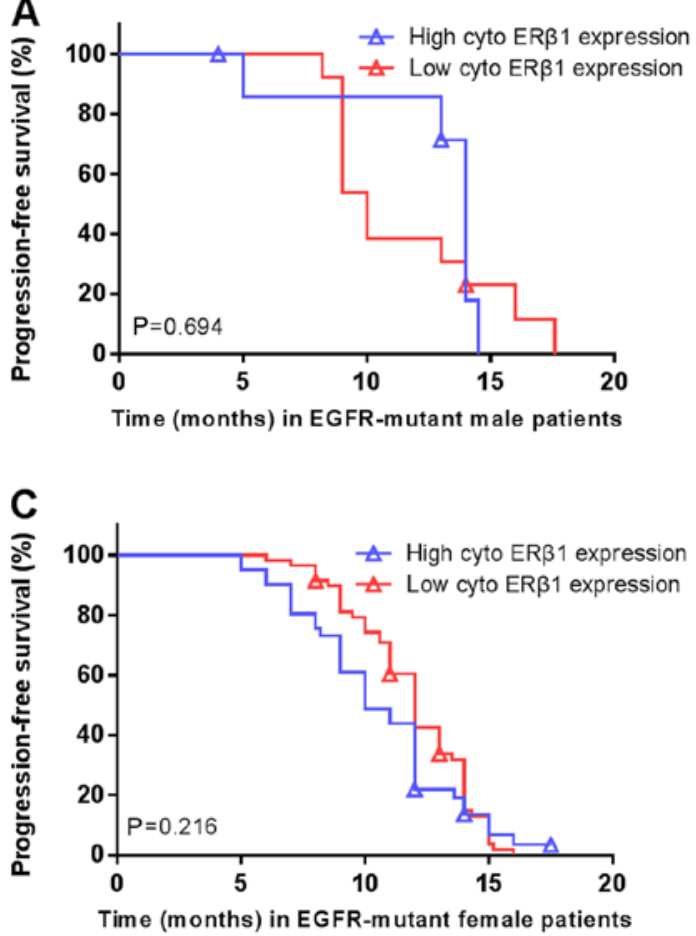

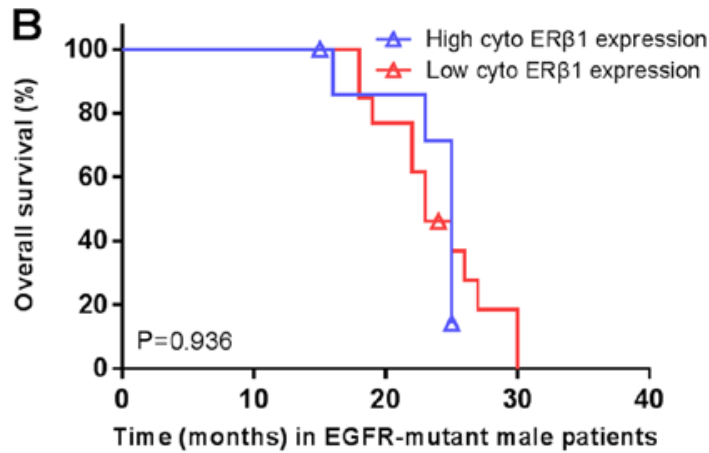

D

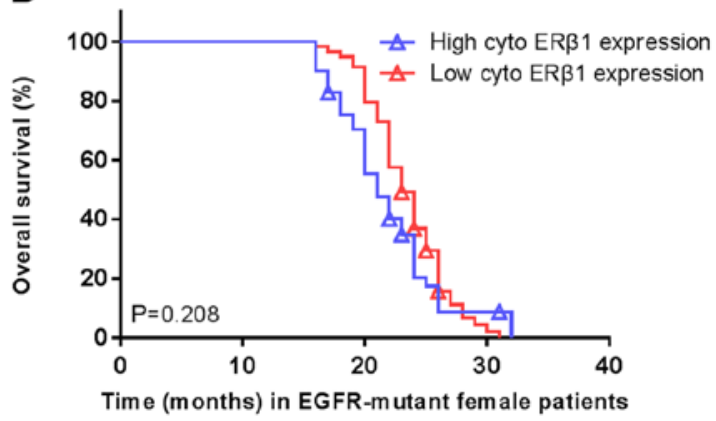

Figure 7. Cytoplasmic ER $\beta 1$ expression is not associated with the survival of patients. There was no significant difference in the (A) PFS and (B) OS in male patients with high vs. low cytoplasmic ER $\beta 1$ expression. $\mathrm{P}=0.694 ; \mathrm{P}=0.936$, respectively. (C) $\mathrm{PFS}$ and (D) OS in female patients with high vs. low cytoplasmic ER $\beta 1$ expression. $\mathrm{P}=0.216 ; \mathrm{P}=0.208$, respectively. Symbols represent censored observations. PFS, progression free survival; OS, overall survival; ER $\beta 1$, estrogen receptor $\beta 1$; EGFR, epidermal growth factor receptor; cyto, cytoplasmic.
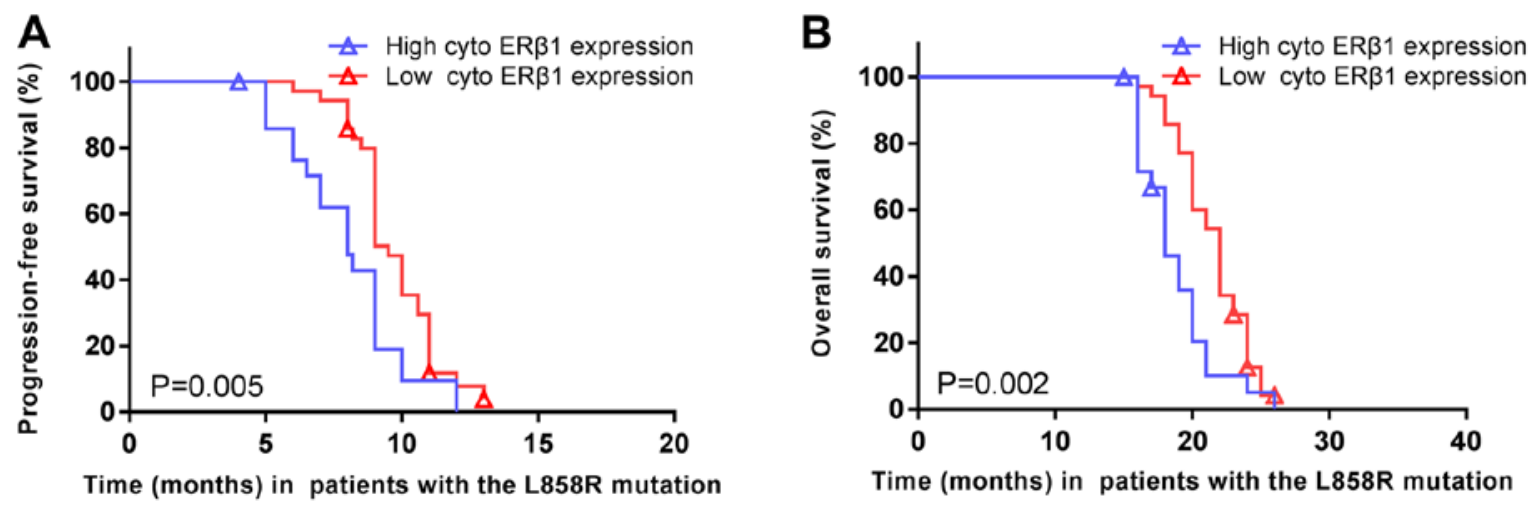

Figure 8. Cytoplasmic expression of ER $\beta 1$ in patients with EGFR exon 21 L858R mutation is associated with survival. (A) Progression-free survival and (B) overall survival were significantly increased in patients with EGFR exon 21 L858R mutated non-small cell lung cancer and low cytoplasmic ER $\beta 1$ expression compared with high expression. $\mathrm{P}=0.005 ; \mathrm{P}=0.002$, respectively. Symbols represent censored observations. EGFR, epidermal growth factor receptor; ER $\beta 1$, estrogen receptor $\beta 1$; cyto, cytoplasmic.

that only ER $\beta 1$ expression was an independent predictor of PFS and OS in patients carrying EGFR 21 L858R mutation.

The present data on EGFR mutations and association with improved PFS and OS of patients with stage IV lung adenocarcinoma following treatment with EGFR-TKI are consistent with earlier studies $(2,3)$. A significantly longer PFS and OS in patients with EGFR Del19 compared with patients with the EGFR exon 21 L858R mutations was observed, which is also consistent with previous studies $(23,24,37)$. The present data highlighted the importance of the EGFR mutation status in association with survival of patients with lung adenocarcinoma following treatment with EGFR-TKI. Previous studies demonstrated that a high frequency of EGFR mutations occurred in Asian patients with advanced non-tobacco smoking lung adenocarcinoma (38) and treatment of these patients with EGFR-TKI may effectively control disease progression and prolong PFS (20).

The incidence of lung adenocarcinoma is increasing in a number of countries; for example, $\sim 40 \%$ of all lung cancer cases are adenocarcinomas in the US (39). Lung adenocarcinoma can occur in tobacco smokers and non-smokers $(39,40)$, and can carry a number of gene mutations, including KRAS, EGFR (20\%), HER2 (2\%), ALK receptor tyrosine kinase, BRAF, PIK3CA, MET or p53 (41). EGFR mutations in lung adenocarcinoma were first identified in 2004 and more frequent in East Asia compared with Western countries $(42,43)$. 

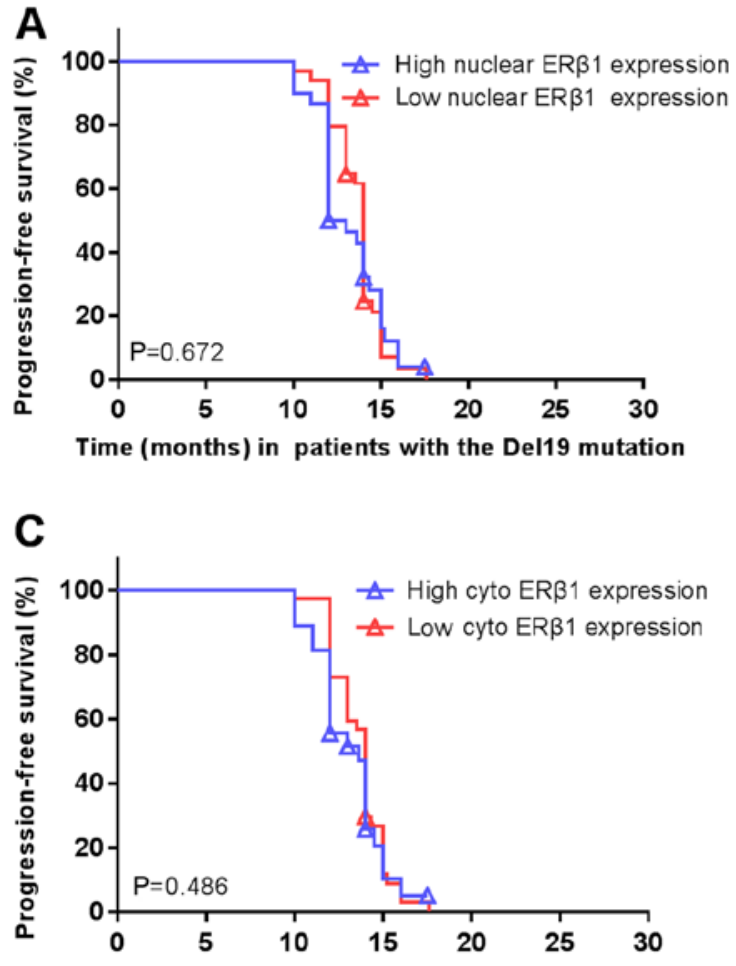

Time (months) in patients with the Del19 mutation Del19 EGFR mutated NSCLC with high vs. low cytoplasmic ER $\beta 1$ expression. $\mathrm{P}=0.486 ; \mathrm{P}=0.661$, respectively. Symbols represent censored observations. EGFR, epidermal growth factor receptor; NSCLC, non-small cell lung cancer; PFS, progression free survival; OS, overall survival; ER $\beta 1$, estrogen receptor $\beta 1$; cyto, cytoplasmic.

Table III. Association of EGFR mutations with ER $\beta 1$ expression in 201 lung adenocarcinoma tissue samples.

\begin{tabular}{|c|c|c|c|c|}
\hline \multirow[b]{2}{*}{ ER $\beta 1$ expression } & \multirow[b]{2}{*}{$\mathrm{n}$} & \multicolumn{2}{|c|}{ EGFR mutation, $\mathrm{n}(\%)$} & \multirow[b]{2}{*}{ P-value } \\
\hline & & Del19 & Exon $21 \mathrm{~L} 858 \mathrm{R}$ & \\
\hline Cytoplasmic & & & & 0.63 \\
\hline High & 50 & $27(42.2)$ & $23(39.6)$ & \\
\hline Low & 72 & $37(57.8)$ & $35(60.4)$ & \\
\hline Nuclear & & & & 0.26 \\
\hline High & 63 & $30(47.6)$ & $33(52.4)$ & \\
\hline Low & 59 & $34(57.6)$ & $25(42.4)$ & \\
\hline Both & & & & 0.64 \\
\hline High & 71 & $36(51.9)$ & $35(49.1)$ & \\
\hline Low & 51 & $28(46.8)$ & $23(53.2)$ & \\
\hline
\end{tabular}

EGFR, epidermal growth factor receptor; ER $\beta 1$, estrogen receptor $\beta 1$.

EGFR mutations were identified in exon 18 G719S, exon 19 G719C, and exon 21 L858R or L861Q, each of which results in constitutive activation of the EGFR as an oncogene (44), and are associated with treatment responses to gefitinib and erlotinib (41).

The present data demonstrated that ER $\beta 1$ expression was increased in lung adenocarcinoma tissues, and additionally ER $\beta 1$ expression was significantly increased in patients with
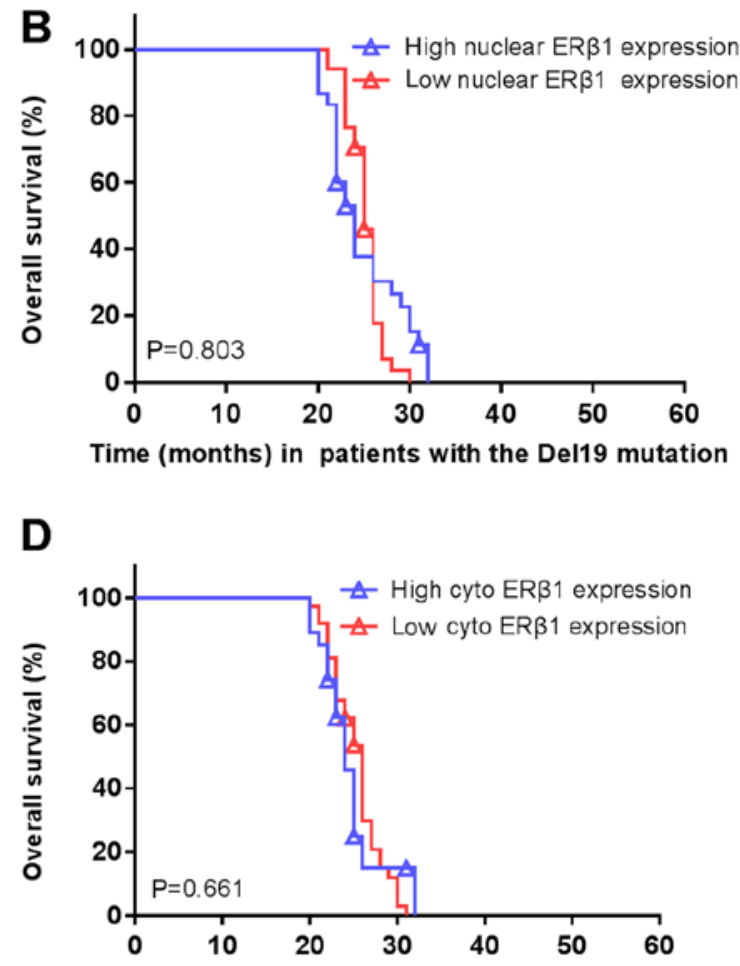

Time (months) in patients with the Del19 mutation
EGFR mutations compared with patients without EGFR mutations, which is consistent with previous publications in patients with lung adenocarcinoma $(13,14,45)$. Estrogen can downregulate levels of EGFR expression, whereas EGF can downregulate the level of ER $\beta$ expression in NSCLC cell lines (46). Tamoxifen, a selective estrogen-receptor modulator, upregulates EGFR expression, whereas gefitinib, an EGFR-TKI, upregulates ER $\beta$ expression (47), suggesting that ER $\beta$ signaling interacts with EGFR signaling in patients with lung adenocarcinoma. Furthermore, the present study assessed the association between ER $\beta 1$ expression and outcome of lung adenocarcinoma patients with EGFR mutations following treatment with EGFR-TKI; however, no significant differences in survival were observed among patients with high or low total, nuclear or cytoplasmic ER $\beta 1$ expression. However, multivariate analysis demonstrated that high cytoplasmic ER $\beta 1$ expression was associated with worse PFS and OS in patients with the EGFR exon 21 L858R mutation following treatment with EGFR-TKI. In contrast to the present study, a previous study demonstrated that increases in ER $\beta 1$ expression in the cytoplasm or nucleus (independently; however, not simultaneously) was associated with poorer prognosis in patients with EGFR-mutated lung adenocarcinoma (16). Another previous study demonstrated that strong ER $\beta 1$ expression was associated with improved prognosis in patients with lung adenocarcinoma treated with EGFR-TKI (15). A possible explanation for the discrepancy between these two studies and the present data may stem from the previous studies not differentiating between patients with EGFR Del19 or exon 21 
Table IV. Multivariate analysis of progression free survival in patients with the epidermal growth factor receptor $21 \mathrm{~L} 858 \mathrm{R}$ mutation.

\begin{tabular}{lccc}
\hline Variable & Hazard ratio & 95\% confidence interval & P-value \\
\hline Sex & 1.901 & $0.807-4.477$ & 0.142 \\
Age (years) & 1.021 & $0.575-1.814$ & 0.942 \\
Tumor brain metastasis & 1.698 & $0.889-3.240$ & 0.109 \\
Smoking status & 0.854 & $0.333-2.187$ & 0.742 \\
Performance status & 1.201 & $0.626-2.303$ & 0.582 \\
Cytoplasmic estrogen receptor- $\beta 1$ expression & 2.847 & $1.456-5.565$ & $0.002^{\text {a }}$ \\
\hline
\end{tabular}

${ }^{\mathrm{a}} \mathrm{P}<0.01$.

Table V. Multivariate analysis of overall survival in patients with the epidermal growth factor receptor 21 L858R mutation.

\begin{tabular}{lccc}
\hline Variable & Hazard ratio & 95\% confidence interval & P-value \\
\hline Sex & 1.598 & $0.668-3.824$ & 0.293 \\
Age (years) & 1.098 & $0.613-1.969$ & 0.753 \\
Tumor brain metastasis & 1.038 & $0.567-1.901$ & 0.903 \\
Smoking status & 1.124 & $0.429-2.944$ & 0.812 \\
Performance status & 1.396 & $0.716-2.720$ & 0.327 \\
Cytoplasmic estrogen receptor- $\beta 1$ expression & 2.639 & $1.383-5.036$ & $0.003^{\mathrm{a}}$ \\
\hline
\end{tabular}

${ }^{\mathrm{a} P}<0.01$.

L858R mutations. However, it is unclear why there was no association of cytoplasmic ER $\beta 1$ expression with prognosis of patients with the Del19 EGFR. Estrogen activates ER and EGFR signaling in cells (48) and ER $\beta 1$ expression in NSCLC may be involved in EGFR-TKI resistance in the treatment of patients with NSCLC. Fu et al (49) recently demonstrated that ER $\beta 1$ induced Erk1/2 and Akt activation, which may have resulted in EGFR-TKI resistance. Ma et al (50) demonstrated that ER directly binds to EGFR to confer tumor cell resistance to EGFR-TKIs, and that a combination of an EGFR-TKI with anti-estrogen therapy may induce tumor cell sensitivity to EGFR-TKI. However, EGFR Del19 or exon 21 L858R mutants are translated into different EGFR protein structures (51). Specifically, in the wild-type EGFR NSCLC, the C-helix is outward rotated and the $\mathrm{N}$-terminal portion of the activation loop forms a helical turn that locks the $\mathrm{C}$-helix in the inactive position. However, the mutant EGFR could destabilize the inactive conformation, e.g., the EGFR L858R mutation has a much larger charged side chain, which will not be able to be contained in the inactive conformation, but can be subsumed within the active and reorganized form of the enzyme (52). Therefore, it is hypothesized that cytoplasmic ER $\beta 1$ binds more tightly to the EGFR 21 L858R mutant protein compared with the Del19 mutant EGFR to confer resistance to TKIs. However, further studies are required to confirm this.

The present study has certain limitations. For example, only immunohistochemistry was performed to analyze ER $\beta 1$ expression in lung cancer tissues; however, RT-qPCR does not easily allow for the determination of the subcellular localization (nuclear or cytoplasmic) of expression in tumor cells and tissue specimens and the presence of a mix of stromal and tumor cells may further complicate the analysis. Furthermore, the All red scoring system of immunohistochemical ER $\beta 1$ expression in tissue specimens was performed according to previous studies $(14,26)$ and the median Allred score was defined as the cutoff value of high vs. low expression, which is different from previously published studies that used other scoring systems and cut-off values. Thus, a standardized scoring system is required for ER $\beta$ expression in NSCLC tissue specimens. Furthermore, the present study had a relatively small sample size and a future study with a larger sample size with multi-institutional participation is preferable to confirm the findings.

The present study demonstrated that cytoplasmic ER $\beta 1$ expression was associated with poor prognosis of patients with stage IV lung adenocarcinoma carrying EGFR exon 21 L858R mutation subsequent to treatment with EGFR-TKI.

\section{Acknowledgements}

Not applicable.

\section{Funding}

No funding was received.

\section{Availability of data and materials}

The datasets used and/or analyzed during the present study are available from the corresponding author on reasonable request. 


\section{Ethics approval and consent to participate}

The present study was approved by the Ethics Committee of Anhui Provincial Cancer Hospital (Hefei, China; approval no. 201705).

\section{Authors' contributions}

$\mathrm{YH}$ and $\mathrm{CH}$ conceived and designed the experiments. Data collection and experiments were performed by MZ, JW and HL. XH, YF, JZ and WC analyzed the data and all authors contributed to the writing of the manuscript.

\section{Patient consent for publication}

Not applicable.

\section{Competing interests}

The authors declare that they have no competing interests.

\section{References}

1. DeSantis CE, Lin CC, Mariotto AB, Siegel RL, Stein KD Kramer JL, Alteri R, Robbins AS and Jemal A: Cancer treatment and survivorship statistics, 2014. CA Cancer J Clin 64: 252-271, 2014.

2. Rosell R, Carcereny E, Gervais R, Vergnenegre A, Massuti B, Felip E, Palmero R, Garcia-Gomez R, Pallares C, Sanchez JM, et al: Erlotinib versus standard chemotherapy as first-line treatment for European patients with advanced EGFR mutation-positive non-small-cell lung cancer (EURTAC): A multicentre, open-label, randomised phase 3 trial. Lancet Oncol 13: 239-246, 2012.

3. Zhou C, Wu YL, Chen G, Feng J,Liu XQ, Wang C,Zhang S, Wang J, Zhou S, Ren S, et al: Erlotinib versus chemotherapy as first-line treatment for patients with advanced EGFR mutation-positive non-small-cell lung cancer (OPTIMAL, CTONG-0802): A multicentre, open-label, randomised, phase 3 study. Lancet Oncol 12: 735-742, 2011.

4. Ettinger DS, Wood DE, Aisner DL, Akerley W, Bauman J, Chirieac LR, D'Amico TA, DeCamp MM, Dilling TJ, Dobelbower M, et al: Non-small cell lung cancer, version 5.2017, NCCN clinical practice guidelines in oncology. J Natl Compr Canc Netw 15: 504-535, 2017.

5. Novello S, Barlesi F, Califano R, Cufer T, Ekman S, Levra MG, Kerr K, Popat S, Reck M, Senan S, et al: Metastatic non-small-cell lung cancer: ESMO clinical practice guidelines for diagnosis, treatment and follow-up. Ann Oncol 27 (Suppl 5): v1-v27, 2016.

6. Kobayashi S, Boggon TJ, Dayaram T, Jänne PA, Kocher O, Meyerson M, Johnson BE, Eck MJ, Tenen DG and Halmos B: EGFR mutation and resistance of non-small-cell lung cancer to gefitinib. N Engl J Med 352: 786-792, 2005.

7. Morgillo F, Della Corte CM, Fasano M and Ciardiello F: Mechanisms of resistance to EGFR-targeted drugs: Lung cancer. ESMO Open 1: e000060, 2016.

8. Thomas C and Gustafsson JA: The different roles of ER subtypes in cancer biology and therapy. Nat Rev Cancer 11: 597-608, 2011.

9. Siegfried JM and Stabile LP: Estrongenic steroid hormones in lung cancer. Semin Oncol 41: 5-16, 2014.

10. Marquez-Garban DC, Chen HW, Fishbein MC, Goodglick L and Pietras RJ: Estrogen receptor signaling pathways in human non-small cell lung cancer. Steroids 72: 135-143, 2007.

11. Siegfried JM: Smoking out reproductive hormone actions in lung cancer. Mol Cancer Res 12: 24-31, 2014.

12. Stabile LP and Siegfried JM: Estrogen receptor pathways in lung cancer. Curr Oncol Rep 6: 259-267, 2004.

13. He Q, Zhang M, Zhang J, Chen Y, He J, Shen J, Liu Y, Zhong S, Jiang L, Yang C, et al: Correlation between epidermal growth factor receptor mutations and nuclear expression of female hormone receptors in non-small cell lung cancer: A meta-analysis. J Thorac Dis 7: 1588-1594, 2015.
14. Nose N, Sugio K, Oyama T, Nozoe T, Uramoto H, Iwata T, Onitsuka T and Yasumoto K: Association between estrogen receptor-beta expression and epidermal growth factor receptor mutation in the postoperative prognosis of adenocarcinoma of the lung. J Clin Oncol 27: 411-417, 2009.

15. Nose $\mathrm{N}$, Uramoto $\mathrm{H}$, Iwata $\mathrm{T}$, Hanagiri $\mathrm{T}$ and Yasumoto $\mathrm{K}$ : Expression of estrogen receptor beta predicts a clinical response and longer progression-free survival after treatment with EGFR-TKI for adenocarcinoma of the lung. Lung Cancer 71: 350-355, 2011.

16. Wang Z, Li Z, Ding X, Shen Z, Liu Z, An T, Duan J, Zhong J, Wu M, Zhao J, et al: ER $\beta$ localization influenced outcomes of EGFR-TKI treatment in NSCLC patients with EGFR mutations. Sci Rep 5: 11392, 2015.

17. Lim VW, Lim WY, Zhang Z, Li J, Gong Y, Seow A and Yong EL: Serum estrogen receptor beta mediated bioactivity correlates with poor outcome in lung cancer patients. Lung Cancer 85: 293-298, 2014.

18. Leung YK, Mak P, Hassan S and Ho SM: Estrogen receptor (ER)-beta isoforms: A key to understanding ER-beta signaling. Proc Natl Acad Sci USA 103: 13162-13167, 2006.

19. Tu HY, Ke EE, Yang JJ, Sun YL, Yan HH, Zheng MY, Bai XY, Wang Z, Su J, Chen ZH, et al: A comprehensive review of uncommon EGFR mutations in patients with non-small cell lung cancer. Lung Cancer 114: 96-102, 2017.

20. Dahabreh IJ, Linardou H, Siannis F, Kosmidis P, Bafaloukos D and Murray S: Somatic EGFR mutation and gene copy gain as predictive biomarkers for response to tyrosine kinase inhibitors in non-small cell lung cancer. Clin Cancer Res 16: 291-303, 2010.

21. Castellanos E, Feld E and Horn L: Driven by mutations: The predictive value of mutation subtype in EGFR-mutated non-small cell lung cancer. J Thorac Oncol 12: 612-623, 2017.

22. Yu HA, Arcila ME, Hellmann MD, Kris MG, Ladanyi M and Riely GJ: Poor response to erlotinib in patients with tumors containing baseline EGFR T790M mutations found by routine clinical molecular testing. Ann Oncol 25: 423-428, 2014.

23. Choi YW, Jeon SY, Jeong GS, Lee HW, Jeong SH, Kang SY, Park JS, Choi JH, Koh YW, Han JH and Sheen SS: EGFR Exon 19 deletion is associated with favorable overall survival after first-line gefitinib therapy in advanced non-small cell lung cancer patients. Am J Clin Oncol 41: 385-390, 2018.

24. Yang JC, Wu YL, Schuler M, Sebastian M, Popat S, Yamamoto N, Zhou C, Hu CP, O'Byrne K, Feng J, et al: Afatinib versus cisplatin-based chemotherapy for EGFR mutation-positive lung adenocarcinoma (LUX-Lung 3 and LUX-Lung 6): Analysis of overall survival data from two randomised, phase 3 trials. Lancet Oncol 16: 141-151, 2015.

25. Mirsadraee S, Oswal D, Alizadeh Y, Caulo A and van Beek E Jr: The 7th lung cancer TNM classification and staging system: Review of the changes and implications. World J Radiol 4: 128-134, 2012.

26. Malalasekera A, Tan CSY, Phan V, Yip PY, Vardy J, Clarke SJ and Kao S: Eastern cooperative oncology group score: Agreement between non-small-cell lung cancer patients and their oncologists and clinical implications. Cancer Treat Commun 5: 17-21, 2016.

27. Eisenhauer EA, Therasse P, Bogaerts J, Schwartz LH, Sargent D, Ford R, Dancey J, Arbuck S, Gwyther S, Mooney M, et al: New response evaluation criteria in solid tumours: Revised RECIST guideline (version 1.1). Eur J Cancer 45: 228-247, 2009.

28. Lopez-Rios F, Angulo B, Gomez B, Mair D, Martinez R, Conde E, Shieh F, Tsai J, Vaks J, Current R, et al: Comparison of molecular testing methods for the detection of EGFR mutations in formalin-fixed paraffin-embedded tissue specimens of non-small cell lung cancer. J Clin Pathol 66: 381-385, 2013.

29. Abe K, Miki Y, Ono K, Mori M, Kakinuma H, Kou Y, Kudo N, Koguchi M, Niikawa H, Suzuki S, et al: Highly concordant coexpression of aromatase and estrogen receptor beta in non-small cell lung cancer. Hum Pathol 41: 190-198, 2010.

30. Chen W, Zheng R, Zhang S, Zeng H, Fan Y, Qiao Y and Zhou Q: Esophageal cancer incidence and mortality in China, 2010. Thorac Cancer 5: 343-348, 2014.

31. Burns TF and Stabile LP: Targeting the estrogen pathway for the treatment and prevention of lung cancer. Lung Cancer Manag 3: 43-52, 2014.

32. Hsu LH, Liu KJ, Tsai MF, Wu CR, Feng AC, Chu NM and Kao SH: Estrogen adversely affects the prognosis of patients with lung adenocarcinoma. Cancer Sci 106: 51-59, 2015.

33. Ma L, Zhan P, Liu Y, Zhou Z, Zhu Q, Miu Y, Wang X, Jin J, Li Q, Lv T and Song Y: Prognostic value of the expression of estrogen receptor $\beta$ in patients with non-small cell lung cancer: A meta-analysis. Transl Lung Cancer Res 5: 202-207, 2016. 
34. Schwartz AG, Prysak GM, Murphy V, Lonardo F, Pass H, Schwartz J and Brooks S: Nuclear estrogen receptor beta in lung cancer: Expression and survival differences by sex. Clin Cancer Res 11: 7280-7287, 2005.

35. Skov BG, Fischer BM and Pappot H: Oestrogen receptor beta over expression in males with non-small cell lung cancer is associated with better survival. Lung Cancer 59: 88-94, 2008.

36. Skjefstad K, Grindstad T, Khanehkenari MR, Richardsen E, Donnem T, Kilvaer T, Andersen S, Bremnes RM, Busund LT and Al-Saad S: Prognostic relevance of estrogen receptor $\alpha, \beta$ and aromatase expression in non-small cell lung cancer. Steroids 113: 5-13, 2016.

37. Sutiman N, Tan SW, Tan EH, Lim WT, Kanesvaran R, Ng QS, Jain A, Ang MK, Tan WL, Toh CK and Chowbay B: EGFR mutation subtypes influence survival outcomes following first-line gefitinib therapy in advanced asian NSCLC patients. J Thorac Oncol 12: 529-538, 2017.

38. Shi Y, Au JS, Thongprasert S, Srinivasan S, Tsai CM, Khoa MT, Heeroma K, Itoh Y, Cornelio G and Yang PC: A prospective, molecular epidemiology study of EGFR mutations in asian patients with advanced non-small-cell lung cancer of adenocarcinoma histology (PIONEER). J Thorac Oncol 9: 154-162, 2014.

39. Stewart BW and Wild CP (eds.): World Cancer Report 2014. World Health Organization, IARC Publications, Lyon, France pp. 489-508, 2014

40. Pao W, Miller V, Zakowski M, Doherty J, Politi K, Sarkaria I, Singh B, Heelan R, Rusch V, Fulton L, et al: EGF receptor gene mutations are common in lung cancers from 'never smokers' and are associated with sensitivity of tumors to gefitinib and erlotinib. Proc Natl Acad Sci USA 101: 13306-13311, 2004.

41. Greulich H: The genomics of lung adenocarcinoma: Opportunities for targeted therapies. Genes Cancer 1: 1200-1210, 2010.

42. Paez JG, Jänne PA, Lee JC, Tracy S, Greulich H, Gabriel S, Herman P, Kaye FJ, Lindeman N, Boggon TJ, et al: Mutations in lung cancer: Correlation with clinical response to gefitinib therapy. Science 304: 1497-1500, 2004.

43. Lynch TJ, Bell DW, Sordella R, Gurubhagavatula S, Okimoto RA, Brannigan BW, Harris PL, Haserlat SM, Supko JG, Haluska FG, et al: Activating mutations in the epidermal growth factor receptor underlying responsiveness of non-small-cell lung cancer to gefitinib. N Engl J Med 350: 2129-2139, 2004.
44. Greulich H, Chen TH, Feng W, Jänne PA, Alvarez JV, Zappaterra M, Bulmer SE, Frank DA, Hahn WC, Sellers WR and Meyerson M: Oncogenic transformation by inhibitor-sensitive and -resistant EGFR mutants. PLoS Med 2: e313, 2005.

45. Hsu LH, Chu NM and Kao SH: Estrogen, estrogen receptor and lung cancer. Int J Mol Sci 18: E1713, 2017.

46. Stabile LP, Lyker JS, Gubish CT, Zhang W, Grandis JR and Siegfried JM: Combined targeting of the estrogen receptor and the epidermal growth factor receptor in non-small cell lung cancer shows enhanced antiproliferative effects. Cancer Res 65: 1459-1470, 2005.

47. Shen H, Yuan Y, Sun J, Gao W and Shu YQ: Combined tamoxifen and gefitinib in non-small cell lung cancer shows antiproliferative effects. Biomed Pharmacother 64: 88-92, 2010.

48. Zhao XZ, Liu Y, Zhou LJ, Wang ZQ, Wu ZH and Yang XY: Role of estrogen in lung cancer based on the estrogen receptor-epithelial mesenchymal transduction signaling pathways. OncoTargets Ther 8: 2849-2863, 2015.

49. Fu S, Liu C, Huang Q, Fan S, Tang H, Fu X, Ai B, Liao Y and Chu Q: Estrogen receptor $\beta 1$ activation accelerates resistance to epidermal growth factor receptor-tyrosine kinase inhibitors in non-small cell lung cancer. Oncol Rep 39: 1313-1321, 2018.

50. Ma S, Yin N, Qi X, Pfister SL, Zhang MJ, Ma R and Chen G: Tyrosine dephosphorylation enhances the therapeutic target activity of epidermal grow th factor receptor (EGFR) by disrupting its interaction with estrogen receptor (ER). Oncotarget 6: 13320-13333, 2015.

51. Rosell R, Taron M, Reguart N, Isla D and Moran T: Epidermal growth factor receptor activation: How exon 19 and 21 mutations changed our understanding of the pathway. Clin Cancer Res 12: 7222-7231, 2006.

52. Yun CH, Boggon TJ, Li Y, Woo MS, Greulich H, Meyerson M and Eck MJ: Structures of lung cancer-derived EGFR mutants and inhibitor complexes: Mechanism of activation and insights into differential inhibitor sensitivity. Cancer Cell 11: 217-227, 2007.

This work is licensed under a Creative Commons Attribution-NonCommercial-NoDerivatives 4.0 International (CC BY-NC-ND 4.0) License. 